\title{
Non-Disputing Party Participation in ICSID Disputes: Faux Amici?
}

\section{Nicolette Butler ${ }^{1}$}

Published online: 24 April 2019

(c) The Author(s) 2019

\begin{abstract}
This article employs a mixed methodological approach to evaluate non-disputing party (NDP) participation by means of amici curiae submissions in investment disputes settled by the International Centre for the Settlement of Investment Disputes (ICSID). The work presents and analyzes statistics on NDP participation in ICSID cases in order to investigate whether amicus submissions are a suitable vehicle for the incorporation of the views of NDPs, and whether they contribute to the development of international investment law and policy. The article argues that amicus briefs are a welcome addition to the ICSID arbitral process in theory, having contributed to the enhancement of the rule of law in investment arbitration through increased transparency. However, the level of NDP participation that amicus briefs provide within ICSID is minimal, and the extent to which they may affect the final outcome of the case is very much at the discretion of the individual tribunal. In light of this, and recognizing previous research that has noted the potential benefits of amici curiae submissions in dispute settlement processes (investment and otherwise), this article will go on to suggest reforms to enhance the participation of NDPs in ICSID arbitration. This will, in turn: contribute to the development of international investment law and policy; increase its integration with other branches of public international law (namely human rights); and enhance transparency and respect for the rule of law.
\end{abstract}

Keywords International investment law · Investor-state dispute settlement (ISDS) · Investment arbitration - International Centre for the Settlement of Investment Disputes (ICSID) · Human rights · Amici curiae

Nicolette Butler

nicolette.butler@manchester.ac.uk

1 University of Manchester, Manchester, UK 


\section{Introduction}

Investment dispute settlement (and more broadly), the law of foreign investment is at a major crossroads. ${ }^{1}$ Critics of investment treaty arbitration focus on two deficiencies of the current system. Commentators allege that the current system lacks legitimacy $^{2}$ and transparency. ${ }^{3}$ Both of these deficiencies broadly relate to a lack of respect for the rule of law. A properly functioning mechanism for the incorporation of the views of non-disputing parties (NDPs) could go a long way towards enhancing legitimacy and transparency in investment treaty arbitration and the investment protection regime, thereby potentially removing the need for the reforms of the system that have been called for in recent years. ${ }^{4}$ The main objective of this work is to analyze the use and utility of amicus submissions in arbitration under the auspices of the International Centre for the Settlement of Investment Disputes (ICSID). The article aims to investigate: firstly, whether amicus submissions provide a suitable vehicle for the incorporation of NDP views in ICSID arbitration; and secondly, whether they contribute to the development of international investment law, the enhancement of transparency and respect for the rule of law. These aims will be achieved by utilizing a mixed methodology, including empirical and doctrinal approaches. There has been very little research carried out on the incorporation of NDP views in ICSID arbitration. Certainly, the mixed methodological approach utilised in this work has not been applied to the study of NDP participation in ICSID proceedings previously.

The article will argue that, in theory, amicus submissions are a welcome addition to the ICSID arbitral process as they provide greater transparency which, in turn, enhances the rule of law. However, as will be demonstrated by the statistics and analysis herein, the level of NDP participation that amicus submissions provide in practice within the ICSID framework is disappointingly minimal, and the extent to which they may affect the final outcome of the case is very much at the discretion of the tribunal. In light of this, and recognizing previous research ${ }^{5}$ that has highlighted the potential benefits of amicus submissions in dispute settlement processes (investment and otherwise), this article will go on to propose two approaches to reforming

\footnotetext{
${ }^{1}$ Investment law is thought to be at a key juncture. Many commentators have criticized the fact that substantive additional protections are available to foreign investors, as well the fact that they are able to utilize investment arbitration to unilaterally 'sue' the investment host state. Procedurally, investment arbitration has also been the subject of much criticism from academics, practitioners and civil society. See for example Stern (2011); Waibel, Kaushal, Chung and Balchin (2010); Hindelang and Krajewski (2016); Kulick (2016); de Mestral (2017).

2 See for example Franck (2005), p. 1521; Leader (2006), p. 657; van Harten (2005), p. 600.

3 See for example Dimsey (2008), pp. 36-37; Paulsson and Rawding (1995), p. 303; Waibel, Kaushal, Chung and Balchin (2010).

4 See for example IIA Issues Note, 'Improving investment dispute settlement: UNCTAD policy tools', https://unctad.org/en/PublicationsLibrary/diaepcb2017d8_en.pdf (accessed 28 September 2018).

5 Commentators have examined the benefits of amicus submissions specifically in investment arbitration e.g. van Duzer (2007), p. 681; Blackaby et al. (2010) and Zachariasiewicz (2012), p. 205. Scholars have also recognized the benefits of amicus submissions in dispute settlement processes such as litigation and arbitration more generally e.g. de Brabandere (2011), p. 85; Shelton (1994), p. 611; Bartholomeusz (2005), p. 209. Note that some authors have questioned the utility of amicus submissions e.g. Wiik (2018).
} 
the rules and practice concerning NDP participation within the ICSID framework. Such reforms could maximize the participation of non-disputing actors in the arbitral process, and contribute to the development of international investment law and its increased integration with other branches of international law, e.g. human rights law.

In order to achieve the aims set out above, the article is structured in seven parts. This section has provided an introduction to the study and an overview of the article. Section 2 will give a brief summary of the background and context of the research. Section 3 will explain and justify the research methodology utilised in this study. Section 4 will present and critically analyse the statistical results of the study. Section 5 will provide a detailed critical analysis of key cases highlighted by the empirical portion of the work. Based on the findings of the study, Sect. 6 will present two recommendations for the reform of rules relating to and the practice surrounding amicus submissions before ICSID tribunals. Section 7 will present a number of concluding remarks.

\section{Background}

\subsection{Significance of Amici Curiae}

In international law, there is no single authoritative definition of 'amicus curiae ${ }^{6}$; the term broadly translates from Latin as 'friend of the court'. ${ }^{7}$ Practically, amici curiae enable non-disputing third parties to address courts or tribunals in order to assist judges or arbitrators by providing different information, expertise or insight to that provided by the parties themselves. In practice, amici curiae participation is usually achieved by means of a written submission to the court or tribunal, though they are not officially limited to such. ${ }^{8}$

\subsection{Amici Curiae Before Investment Tribunals}

Amici curiae briefs are not a new phenomenon; such submissions can be traced back to Roman times. ${ }^{9}$ Amici curiae submissions are now widely accepted by many international adjudicatory bodies, such as the European Court of Human Rights, ${ }^{10}$ the World Trade Organization Dispute Settlement Body ${ }^{11}$ and the International Tribunal

\footnotetext{
${ }^{6}$ Crema (2012), p. 93.

7 Bartholomeusz (2005), p. 211.

8 See Crema (2012).

9 Chandra Mohan (2010), p. 352.

${ }^{10}$ Rule 44 of the Rules of Court, available at https://www.echr.coe.int/Documents/Rules_Court_ENG. pdf (accessed 15 October 2018).

11 Art. 10 WTO Dispute Settlement Understanding, https://www.wto.org/english/tratop_e/dispu_e/ dsu_e.htm (accessed 15 October 2018).
} 
for the Law of the Sea. ${ }^{12}$ Their widespread acceptance by adjudicatory bodies can be interpreted as evidence of their utility and value.

Comparisons can also be drawn between investment and other fields of international law in which amicus submissions are accepted, which in turn, provides support for the utilization of amicus submissions in investment disputes. International trade law, for example has many parallels with investment law; the two fields have been widely accepted to intertwine and overlap. ${ }^{13}$ Many of the public interest concerns and problems seen in international trade disputes, e.g. environmental degradation and human rights abuses, are often also seen in investment cases. Therefore, if we accept amicus submissions in trade disputes, it follows that amicus submissions should also be accepted in investment disputes. ${ }^{14}$

Although amicus submissions have been widely accepted by various adjudicatory bodies for many years, the practice of accepting such submissions in investment disputes is relatively novel. Amicus applications and submissions were first seen in investment cases from 2001, in the landmark case of Methanex ${ }^{15}$ [which was settled by an ad hoc tribunal under the Rules of the United Nations Commission on International Trade Law (UNCITRAL)]. Despite the acceptance by the tribunal established in accordance with the UNCITRAL Rules in Methanex, tribunals constituted under the auspices of the ICSID were initially hesitant to allow NDP participation in investment disputes. Indeed in the Aguas del Tunari case, ${ }^{16}$ an ICSID tribunal refused to accept amicus submissions due to the parties' unwillingness to accept such submissions. The tribunal asserted that the 'interplay of the ICSID Convention and the BIT [bilateral investment treaty], and the consensual nature of arbitration' ${ }^{17}$ meant that the decision as to whether or not to accept third party submissions should be left to the parties themselves. This decision was fiercely criticized, ${ }^{18}$ and with good reason. Though the concept of party autonomy ${ }^{19}$ is a central pillar of arbitration (largely due to its association with commercial disputes), in investment disputes, where important issues of public interest are often at stake, the centrality of the role of party autonomy is questionable.

As a result of the criticism surrounding the Aguas del Tunari case, subsequent ICSID tribunals took a different stance on the issue of NDP participation.

\footnotetext{
12 Arts. 31 and 32 Statute of the International Tribunal for the Law of the Sea, https://www.itlos.org/filea dmin/itlos/documents/basic_texts/statute_en.pdf (accessed 15 October 2018).

13 See for example Footer (2013).

14 For more information on amicus participation in WTO disputes see: Mavroidis (2002); Cawley (2004), p. 47; and Howse (2007).

15 Methanex Corporation v. USA (2001), Decision of the tribunal on petitions from third parties to intervene as 'amici curiae', https://www.italaw.com/sites/default/files/case-documents/ita0517_0.pdf (accessed 3 July 2018).

16 Aguas del Tunari v. Republic of Bolivia (2002) (ICSID Case No. ARB/02/3).

17 Choudhury (2008), p. 814.

18 Mistelis (2005), p. 169.

19 Party autonomy for the purposes of this article is used to refer to the broad concept of parties to a dispute being free to make choices regarding any aspect of the dispute. The term is not utilized in the narrower sense of referring to parties' choice of law applicable to the substance of the dispute.
} 
Accordingly, the first ICSID arbitrators to accept an amicus submission were those presiding over the 2005 Vivendi case. ${ }^{20}$ Ultimately, this case led to the amendment of ICSID Rule $37 .{ }^{21}$ The amended Rule 37 explicitly enables NDPs to apply to file an amicus brief, and further, established the criteria for their participation. ${ }^{22}$ The amended Rule 37 has subsequently been invoked on over 50 occasions, ${ }^{23}$ and 'has resulted in amicus submissions from diverse parties such as environmental groups and the European Union'. ${ }^{24}$

\subsection{Rationale for the Acceptance of Amici Curiae in Investment Disputes}

The theory of the rule of law may be utilised to justify amici curiae participation in legal disputes. Although Reinisch asserts that 'the notion [of the rule of law] itself if not sufficiently clear', ${ }^{25}$ the UN definition of the concept helpfully notes that the concept relates to: all persons, entities and the state being accountable to law; equality before the law and in its enforcement; independency of adjudication; fairness in the application of legal rules; participation in decision making; legal certainty; avoidance of arbitrariness; and procedural and legal transparency. ${ }^{26}$ It is clear from the UN definition that the rule of law is a wide concept, encompassing many different dimensions. Some of these dimensions are more relevant than others to the participation of amici curiae in investment arbitration; for example, amicus submissions clearly have the potential to enhance both procedural and legal transparency. Transparency can relate to various issues, including public access to case documents, open hearings, the publication of awards, as well as allowing NDPs to participate in disputes through the submission of amicus briefs.

Transparency (and more specifically NDP participation) is not a feature of commercial arbitration; indeed, private parties have favoured such arbitration for the resolution of commercial disputes precisely because it preserves confidentiality. ${ }^{27}$ However, different concerns arise in hybrid (investor-state) arbitration, largely due to the fact that a state is party to the proceedings. A state is a public entity, and is therefore responsible for the well-being of its citizens; such well-being may be compromised by investment, which can affect important issues of public interest, e.g. the provision of important public services, ${ }^{28}$ environmental degradation ${ }^{29}$ and

\footnotetext{
${ }^{20}$ Suez, Sociedad General de Aguas de Barcelona S.A. and Vivendi Universal S.A v. Argentine Republic (ICSID Case No. ARB/03/19).

21 Antonietti (2006), p. 427.

22 ICSID website, 'The ICSD rules amendment process', https://icsid.worldbank.org/en/documents/about /icsid\%20rules\%20amendment\%20process-eng.pdf (accessed 16 July 2018).

23 ICSID website, 'Decisions on non-disputing party participation', https://icsid.worldbank.org/en/Pages/ process/Decisions-on-Non-Disputing-Party-Participation.aspx (accessed 2 September 2018).

24 ICSID website, 'The ICSD rules amendment process', supra n. 22.

25 Reinisch (2016), p. 291.

${ }^{26} \mathrm{UN}$, 'Report of the Secretary-General on the rule of law and transitional justice in conflict and postconflict societies' (2004), S/2004/616, para. 6, as cited in Reinisch (2016).

27 Trakman (2014), p. 1.

28 See for example Biwater Gauff Ltd v. United Republic of Tanzania (ICSID Case No. ARB/05/22).

${ }^{29}$ Burlington Resources Inc v. Republic of Ecuador (ICSID Case No. ARB/08/5).
} 
government regulations designed to enhance public welfare. ${ }^{30}$ Due to the fact that such public interest issues arise in investment claims, some NDPs may arguably have a legitimate interest in the outcome of the case. Additionally, the state will use public money to fund its defence of investment claims, as well as to pay any damages awarded. Moreover, there is recognition that investment arbitration is transferring decision making from the national to the international level; indeed some commentators have suggested that investment arbitration is creating a form of 'global administrative law'. ${ }^{31}$ For all of these reasons then, a high degree of transparency in investment arbitration (higher than in commercial arbitration) is justifiable. Amicus submissions increase transparency, and as transparency forms part of the rule of law, amicus submissions ultimately enhance the rule of law itself.

Despite the proven utility and necessity of amici curiae in investment arbitration, some authors ${ }^{32}$ contend that there are potential drawbacks or disadvantages of amici curiae. Firstly, it is suggested that amicus applications place serious practical burdens on the disputing parties and decision makers, particularly where the court or tribunal is in receipt of an unmanageable number of submissions. Whilst it is true that amicus applications can lead to increased costs and delays, especially if a large number of submissions are received, it is submitted that such burdens are ultimately worthwhile. Amicus submissions can provide new information and perspective on the case, which may affect the outcome of the dispute and lead to a fairer decision in the long run; this is important in investment disputes when important public interest issues are often at stake. Additionally, costs and delays can be minimised by the careful drafting of procedural rules with strict time and submission limits. Moreover, reasonable restrictions can be placed on those wishing to submit a brief, e.g. requiring a legitimate interest in the disputes. It is also suggested that amicus briefings could compromise the parties' rights and position in the proceeding, e.g. skewing of the tribunal's perception of the case due to public reactions to the case. This argument is not very convincing; arbitrators are highly professional individuals, who are usually very well qualified and experienced. They are unlikely to be swayed solely by amicus submissions at the expense of the application of the law to the facts. Additionally, arbitrators have a duty to remain independent and impartial. There is also a risk that amicus submissions politicize disputes, which might lead to a delegitimization of the dispute settlement process and increased lobbyism. The fact of the matter is that it is the subject of the dispute which is often political, not the fact that amicus submissions are allowed. Therefore, potential politicization is not a strong enough reason not to allow amicus applications and submissions. Additionally, de-legitimization can be avoided by the careful drafting of procedural rules surrounding the requirements of amicus applications to ensure that there is no conflict of interest. In terms of lobbyism, it is argued that arbitrators should be relied upon to recognise signs of lobbyism and be wise to attempts by NDPs to lobby. Again, this criticism of amicus submissions seems to unfairly question the abilities and qualification of arbitrators. Another potential criticism suggests that amicus participation

\footnotetext{
${ }^{30}$ Philip Morris Brands SARL and others v. Republic of Uruguay (ICSID Case No. ARB/10/7).

31 Van Harten and Loughlin (2006), p. 121.

${ }^{32}$ For an overview of the alleged disadvantages, see Wiik (2018), pp. 64-72.
} 
might disadvantage developing states, owing to the fact that most amici curiae are submitted by well-funded western non-governmental organisations (NGOs). This can be easily overcome by publicising the opportunity to submit amicus applications in the host state very thoroughly and encouraging potential amicus applicants to seek pro bono assistance from informed organisations, e.g. law firms, NGOs and charities. Finally, it is suggested that amicus submissions lead to the denaturing of the judicial function (which is to hear and decide disputes). It is alleged that the arbitrators may try to satisfy the interests of the general public in a manner akin to legislating, rather than actually adjudicating the dispute at hand. Again, this argument is unconvincing as it does not take into account the quality and qualification of arbitrators; their professionalism and abilities should not be so easily doubted.

It is therefore contended that the potential drawbacks of amicus submissions are greatly outweighed by the potential benefits that they can have on dispute settlement procedures (in particular investment arbitration). Such a positive view of amicus submissions has been endorsed by various commentators. ${ }^{33}$ This research therefore proceeds on the basis of a strong presumption of the benefit of amici curiae participation in investment arbitration. Amicus submissions provide a higher level of transparency in investment arbitration, which, in turn, enhances the rule of law.

\section{Methodology}

As set out above, the central aim of this study is to analyse the use and utility of amicus submissions in ICSID arbitration. In order to achieve this aim, a mixed methodological approach is employed, comprising both empirical and doctrinal elements.

An empirical analysis of the participation of NDPs in ICSID arbitration was undertaken in this study. Accordingly, an enquiry into the number of decisions by ICSID tribunals on applications by NDPs was carried out. This information was readily and publicly available on the ICSID website. ${ }^{34}$ The website demonstrated that up to 9 July 2018, there had been 58 decisions $^{35}$ on applications by NDPs. These 58 decisions included applications in concluded as well as currently pending cases. This study is only concerned with the applications by NDPs in concluded cases. Given that the aim of the study is to examine NDP participation in ICSID arbitration, logically, the best way to achieve this aim would be to analyse the number of NDP applications in concluded cases, and to examine whether NDP applications that were accepted (and subsequently amicus briefs were submitted) ultimately affected the outcome of the case.

Therefore, a thorough analysis of the 58 decisions on NDP participation was undertaken, beginning with the Vivendi case. ${ }^{36}$ It was discovered that only 16 of the

\footnotetext{
33 See supra n. 5.

34 ICSID website, 'Decisions on non-disputing party participation', supra n. 23.

35 Ibid.

36 Suez, Sociedad General de Aguas de Barcelona S.A. and Vivendi Universal S.A v. Argentine Republic, supra $\mathrm{n} .20$.
} 
58 decisions pertain to concluded cases. Accordingly, an in-depth examination of these 16 cases was carried out, in order to ascertain; firstly, whether the application by a NDP to submit a brief was accepted; and if it was accepted, secondly, whether a final award was rendered in the case. If a final award was rendered, whether the amicus brief had either a direct or indirect effect on the final award rendered by the tribunal was examined.

For the purposes of this research, direct effect is defined as being where the tribunal cited or made explicit reference to the amicus submission (over and above a reference simply in terms of procedural recap). Indirect effect is defined as being where the tribunal did not cite or make explicit reference to the amicus submission; however, an inspection of the amicus submission and the eventual award reveals that the amicus submission influenced the tribunal's decision in some way.

One possible theory for the different effects of amicus submissions on the outcome of the cases is that it could be explained by differences in attitudes of individual arbitrators. In order to investigate this possibility, the arbitrators' identities in the 16 concluded cases were examined. This enabled a detailed analysis to be carried out into potential crossovers and patterns in terms of individual arbitrators.

It should be noted that a decision was made not to examine any further proceedings i.e. Article 52 ICSID annulment decisions; namely because annulment would be based purely on procedural matters as per Article 52 of the ICSID Convention (and not on the merits of the case). Therefore, an analysis of annulment proceedings would be pointless, as such proceedings would not deal with the merits; rather, they would deal with purely procedural issues.

The scope of the study has been limited to ICSID investment treaty arbitration only. This decision is based on the fact that statistically, the majority of investment disputes are settled under the auspices of the ICSID Convention. Indeed, ICSID has administered over $70 \%$ of all known investment disputes, making it the most important venue for investment dispute resolution. ${ }^{37}$ In addition to being the most significant venue for investment arbitration, limitation to ICSID arbitration was decided upon for reasons of practicality, including time constraints and the manageability of the study.

It is important to note that for the purposes of this research, other states have not been classified as NDPs. In a number of multilateral investment agreements, e.g. the North American Free Trade Agreement (NAFTA), ${ }^{38}$ express provision is made in the agreement itself for the acceptance of third states' submissions in the event of a dispute to which that state is not party. A number of investment disputes under these agreements have been settled by ICSID. The decision to exclude the non-disputing government in these cases from the definition of NDPs for the purposes of this research is based on the fact that the treaties and agreements themselves have

\footnotetext{
37 ICSID Annual Report (2017), https://openknowledge.worldbank.org/handle/10986/28558 (accessed 28 September 2018).

38 Art. 1128, Chapter 11 NAFTA, https://www.nafta-sec-alena.org/Home/Texts-of-the-Agreement/North -American-Free-Trade-Agreement?mvid=1\&secid=539c50ef-51c1-489b-808b-9e20c9872d25\#A1128 (accessed 15 October 2018).
} 
meant that third party states have always been able to make submissions (written or oral), therefore, they do not represent anything new or exceptional. Accordingly, for the purposes of this work, NDPs refers to non-state third parties.

By undertaking the empirical element of the research, a number of key cases in relation to amicus brief acceptance within ICSID were identified. Accordingly, a more in-depth critical analysis of such cases could be completed. For example, a thorough examination of the cases in which the ICSID tribunal did or did not permit the petition for amicus submission, and an examination of the potential reasons for such decisions could be carried out. Additionally, a critical analysis of the effect of the permitted submission on the outcome of the case was undertaken. This analysis is supported by reference to relevant primary sources, e.g. bilateral investment treaties and secondary sources, e.g. academic literature and writings of other commentators, such as practitioners; this represents the doctrinal element of the study.

\section{Analysis of Statistics}

There have been 309 ICSID cases concluded since Vivendi. ${ }^{39}$ Additionally, there have been 58 decisions on NDP applications by ICSID tribunals since Vivendi ${ }^{40}$ (note that these pertain to both concluded and pending cases). ${ }^{41}$ A total of 16 out of 309 concluded ICSID cases included applications to make submissions by NDPs ${ }^{42}$ since Vivendi. ${ }^{43}$

Out of 16 applications by NDPs, 11 applications were accepted/granted (meaning of course that five were not explicitly accepted ${ }^{44}$ ).

Out of the 16 applications by NDPs, in 13 cases the tribunal went on to render a final award that was made publicly available.

Out of the 16 applications by NDPs, in at least 11 cases the applications were accepted (all or in part); two cases were discontinued (one case was discontinued before a decision was rendered on the NDP application, and in the other a decision seems to have been reached but the outcome remains unpublished); and in three cases the NDP applications were denied.

Out of the 16 applications by NDPs (and of the 11 accepted applications) where a final award was rendered, in six cases the NDP submission had a direct effect on

\footnotetext{
${ }^{39}$ According to the 'Concluded cases with details' page of the ICSID website, https://icsid.world bank.org/en/Pages/cases/ConcludedCases.aspx?status=c, as accessed on 16 July 2018, whereby the most recently concluded case was APCL Gambia B.V. v. Republic of The Gambia (ICSID Case No. $\mathrm{ARB} / 17 / 40)$.

${ }^{40}$ Suez, Sociedad General de Aguas de Barcelona S.A. and Vivendi Universal S.A v. Argentine Republic, supra n. 20.

41 'Decisions on non-disputing party applications', supra $\mathrm{n} .23$.

${ }^{42}$ Ibid.

${ }^{43}$ Suez, Sociedad General de Aguas de Barcelona S.A. and Vivendi Universal S.A v. Argentine Republic, supra n. 20.

${ }^{44}$ Of the five that were not accepted, three applications were denied, one case was discontinued and one case remains unpublished.
} 
the outcome of the case. Out of 11 accepted applications where a final award was rendered, in one case the NDP submission had both a direct and an indirect effect on the outcome of the case (see Table 1 below).

There is some evidence to suggest that since the first acceptance of amici curiae by an ICSID tribunal in Vivendi (case registered in 2003), ICSID tribunals appear to have become more open to accepting amicus submissions. Moreover, it appears that over time, such submissions appear to have had more of an effect on the outcome of the dispute. ${ }^{45}$ This is to be expected; adoption and reliance on new procedures often increases over time. Nonetheless, overall, it can be argued that amicus submissions have been underutilised within ICSID to date.

Given the so-called revolving door ${ }^{46}$ concept in international investment arbitration, it is pertinent to evaluate whether there may be a correlation between the effect of the NDP submission on the outcome of the case and the identity of the arbitrators hearing the case. Therefore, an examination/comparison of outcomes and arbitrators was carried out (see Table 2 below). There is no strong evidence of a correlation between direct or indirect effect on the outcome of the case and the particular arbitrators deciding the case. The only noteworthy statistic is that of the 16 cases including NDP applications, Gary Born was on the panel of arbitrators in three of the cases, and in each of those three cases the amicus submission had a direct effect on the outcome. However, in four other cases where Gary Born was not an arbitrator, there was also a direct effect on the outcome. Therefore, no inference can be made as to the correlation between the effect of an amicus brief and individual arbitrators in these cases.

\section{Analysis of ICSID Concluded Cases Which Included Applications by NDPs}

\subsection{Cases Where NDP Application Was Accepted and There Was a Direct or Indirect Effect on the Outcome}

\subsubsection{The EU NDP Cases: Micula; Electrabel and AES}

In the Micula v. Romania case, ${ }^{47}$ the claimants (Swedish investors) alleged that the introduction and subsequent revocation of certain economic investment incentives by the Romanian government amounted to a breach of investment protection obligations under the Romania-Sweden (2002) BIT. The investors asserted that, in reliance on those investment incentives, and in reliance on the expectation that these incentives would be maintained for a period of ten years, they made substantial

\footnotetext{
45 Cases in which amicus submissions were accepted and the years in which the cases were first registered by ICSID: Vivendi 2003; Micula 2005; Biwater 2005; Merril 2007; Foresti 2007; Electrabel 2007; AES 2007; Pac Rim 2009; Philip Morris 2010; Eli Lilly 2014; and Bear Creek 2014.

46 For more on this concept, see for example Langford et al. (2017), p. 301.

47 Micula (and others) v. Romania (ICSID Case No. ARB05/20).
} 
Table 1 The 16 ICSID concluded cases which included applications by NDPs (other than third states) since Vivendi

\begin{tabular}{llllll}
\hline & Case & Final award? & 'Winner'? & Amicus granted? & Effect on outcome? \\
\hline 1 & Vivendi & $\checkmark$ & I & $\checkmark$ & $\times$ \\
2 & Micula & $\checkmark$ & I & $\checkmark$ & Direct \\
3 & Biwater & $\checkmark$ & Neither & $\checkmark$ & Direct \\
4 & Merril & $\checkmark$ & S & $\checkmark$ & $\times$ \\
5 & Foresti & $\times$ & - & $\checkmark$ & - \\
6 & S\&T oil & $\times$ & - & Discontinued & - \\
7 & Electrabel & $\checkmark$ & S & $\checkmark$ & Direct \\
8 & AES & $\checkmark$ & S & $\checkmark$ & Direct \\
9 & Caratube & $\checkmark$ & S & $\times$ & - \\
10 & Apotex & $\checkmark$ & S & $\times$ & - \\
11 & Pac Rim & $\checkmark$ & S & $\checkmark$ & $\times$ \\
12 & Phillip Morris & $\checkmark$ & S & $\checkmark$ & Direct \\
13 & Apotex (2) & $\checkmark$ & S & $\times$ & - \\
14 & Eli Lilly & $\checkmark$ & S & $\checkmark(5$ of 9) & Direct \\
15 & Bear Creek & $\checkmark$ & I & $\checkmark$ & Direct and indirect \\
16 & Engie & $\times$ & - & Unknown and discontinued & $\times$ \\
\hline
\end{tabular}

$\mathrm{I}=$ investor(s), $\mathrm{S}=$ state

investments in Romania. When these incentives were withdrawn, the claimants commenced ICSID arbitration, which was ultimately decided in favour of the investor. ${ }^{48}$

The European Commission (hereinafter EC) applied to the tribunal to submit an amicus brief. ${ }^{49}$ This application was granted by the tribunal and the EC subsequently participated by means of an amicus submission in the case. ${ }^{50}$ The brief submitted by the EU argued that the investment incentives were incompatible with the European Community rules on state aid ${ }^{51}$ (and therefore competition law rules). The EC went on to state that compensating the claimants for the loss of these investment incentives (i.e. by way of awarding damages to the investor) would essentially lead to the granting of new state aid on Romania's part, which in itself would amount to another breach of Community obligations by the Romanian government. ${ }^{52}$

\footnotetext{
48 Ibid.

49 See Micula ICSID case details, procedural details, https://icsid.worldbank.org/en/Pages/cases/cased etail.aspx?CaseNo=ARB/05/20 (accessed 1 October 2018).

50 Ibid.

51 See Arts. 107, 108 and 109 of the Treaty on the Functioning of the European Union (TFEU), https:// eur-lex.europa.eu/legal-content/EN/TXT/?uri=celex\%3A12012E\%2FTXT (accessed 15 October 2018).

52 See the procedural history of the case, as detailed in the Commission Decision (EU) 2015/1470 of 30 March 2015 on State aid SA.38,517 (2014/C) (ex 2014/NN) implemented by Romania-Arbitral award Micula v. Romania of 11 December 2013, available at https://eur-lex.europa.eu/legal-content/EN/ TXT/?uri=CELEX\%3A32015D1470 (accessed 1 October 2018).
} 
Table 2 Arbitrators who decided the concluded cases which included applications by NDPs since Vivendi

\begin{tabular}{|c|c|c|}
\hline Case & Effect on outcome & Arbitrators and appointing party \\
\hline Vivendi & None & $\begin{array}{l}\text { J Salacuse (Chair) } \\
\text { G Kauffman-Kohler (C) } \\
\text { P Nikken (R) }\end{array}$ \\
\hline Micula & Direct & $\begin{array}{l}\text { S Alexandrov }(\mathrm{C}) \\
\text { G Abi-Saab }(\mathrm{R}) \\
\text { L Levy (Chair) }\end{array}$ \\
\hline Biwater & Direct & $\begin{array}{l}\text { G Born (C) } \\
\text { B Hanotiau (Chair) } \\
\text { T Landau (R) }\end{array}$ \\
\hline Merril & None & $\begin{array}{l}\text { K Dam }(\mathrm{C}) \\
\text { J Rowley }(\mathrm{R}) \\
\text { F Orrego Vicuna (Chair) }\end{array}$ \\
\hline Foresti & - & $\begin{array}{l}\text { V Lowe (Chair) } \\
\text { C Brower }(\mathrm{C}) \\
\text { J Matthew }(\mathrm{R})\end{array}$ \\
\hline $\mathrm{S} \& \mathrm{~T}$ & - & $\begin{array}{l}\text { H Van Houtte (Chair) } \\
\text { H Grigera Naon (C) } \\
\text { B Stern (R) }\end{array}$ \\
\hline Electrabel & Direct & $\begin{array}{l}\text { G Kaufmann Kohler (C) } \\
\text { B Stern (R) } \\
\text { V Veeder (Chair) }\end{array}$ \\
\hline AES & Direct & $\begin{array}{l}\text { J Rowley (C) } \\
\text { B Stern (R) } \\
\text { C von Wobeser (Chair) }\end{array}$ \\
\hline Caratube & - & $\begin{array}{l}\text { G Griffith }(\mathrm{C}) \\
\text { K Hossain (R) } \\
\text { K Bockstiegel (Chair) }\end{array}$ \\
\hline Apotex & - & $\begin{array}{l}\text { C Davidson (C) } \\
\text { F Smith (R) } \\
\text { T Landau (Chair) }\end{array}$ \\
\hline Pac Rim & None & $\begin{array}{l}\text { G Santiago Tawil (C) } \\
\text { B Stern }(\mathrm{R}) \\
\text { V Veeder (Chair) }\end{array}$ \\
\hline Phillip Morris & Direct & $\begin{array}{l}\text { G Born }(\mathrm{C}) \\
\text { J Crawford }(\mathrm{R}) \\
\text { P Bernardini (Chair) }\end{array}$ \\
\hline Apotex (2) & - & $\begin{array}{l}\text { J Rowley (C) } \\
\text { J Crook (R) } \\
\text { V Veeder (Chair) }\end{array}$ \\
\hline
\end{tabular}


Table 2 (continued)

\begin{tabular}{lll}
\hline Case & Effect on outcome & Arbitrators and appointing party \\
\hline Eli Lilly & Direct & G Born (C) \\
& & D Bethlehem (R) \\
& & A van den Berg (Chair) \\
Bear Creek & Direct and indirect & M Pryles (C) \\
& & P Sands (R) \\
Engie & Unknown (case information not & K Bockstiegel (Chair) \\
& published) & D Williams (C) \\
& & P Bernardini (R) \\
& & K Sachs (Chair) \\
\hline
\end{tabular}

In the final award of 11 December 2013, the tribunal ultimately found in favour of the claimant and ordered the respondent state to pay the investor $\$ 116$ million damages. Once again, the EC claimed that Romania's payment of the damages would itself amount to illegal state aid, and a breach of European Community obligations. ${ }^{53}$ The enforcement of the award remains contested. ${ }^{54}$ Nonetheless, in its final award, the tribunal made several explicit (direct) references to the EC's amicus submission. ${ }^{55}$ However, the arguments of the EC and the respondent state (which were essentially identical) were rejected, and ultimately the investor prevailed in the case. ${ }^{56}$ This case therefore demonstrates that amicus briefs can be useful to tribunals because they cite them, even if such briefs do not lead to the NDP's intended outcome (i.e. in this case, the respondent did not prevail).

In a second case in which the EC participated as an NDP, Electrabel, ${ }^{57}$ a Belgian company brought a case against the Hungarian government for alleged breaches of the Energy Charter Treaty following changes to Hungary's electricity pricing regime, and its decision to terminate a power purchase agreement with Electrabel's Hungarian subsidiary company. The agreement was terminated following an EC decision which stated that such agreements constituted state aid (as prohibited by EU law). ${ }^{58}$ The tribunal ultimately dismissed all of the investor's claims.

Both parties agreed that the ICSID tribunal had jurisdiction to hear the dispute. Nonetheless, the tribunal was nevertheless required to address the EC's jurisdictional objections, which it submitted by way of an amicus curiae brief. The EC asserted that the claims brought amounted to a challenge of the EU decision on state

\footnotetext{
53 See generally, Commission Decision (EU) 2015/1470 of 30 March 2015, ibid.

54 See Viorel Micula and others v. Romania and European Commission (intervenor) [2018] EWCA Civ 1801.

55 Micula (and others) v. Romania (ICSID Case No. ARB05/20), Final Award 11 December 2013, available at https://www.italaw.com/sites/default/files/case-documents/italaw3036.pdf (accessed 1 October 2018).

56 Ibid.

57 Electrabel SA v. Republic of Hungary (ICSID Case No. ARB/07/19).

58 Commission decision 4 June 2008, https://publications.europa.eu/en/publication-detail/-/publication/ dbbe66f5-1d84-4173-b910-0fac7e57aeb9/language-en (accessed 8 October 2018).
} 
aid, and therefore that the dispute should be heard by the EU Courts. Ultimately, the tribunal dismissed the EC's assertion that questions of interpretation of EU law fell exclusively under the jurisdiction of the EU courts. The tribunal did agree that EU Member States had agreed to submit questions of interpretation of EU law to the EU Courts. However, this fact was not relevant to the present dispute, as the case was brought for a breach of the Energy Charter Treaty (and not EU law). The EU's submission is cited extensively in the tribunal's award, ${ }^{59}$ therefore it is submitted that the amicus submission had a direct effect on the outcome of the dispute. One of the reasons that the amicus submission may have been cited so extensively in the final award is that the arguments raised by the EC were different to those raised by the parties. This is an example of how amicus submissions can bring a fresh perspective to ICSID disputes, demonstrating that they can be enormously useful to the tribunal.

The third case in which the EC participated as an NDP, AES, ${ }^{60}$ concerned British investors alleging that Hungary had violated their rights under the Energy Charter Treaty. The EC applied for leave to file an amicus submission, which was ultimately granted by the tribunal. This was actually the first ISCID case (chronologically) in which the Commission submitted an amicus brief. The EC's amicus submission initially challenged the tribunal's jurisdiction (for the same reasons it advanced in the Electrabel case ${ }^{61}$ above). Nonetheless, the tribunal did not accept the argument, due to the fact that the parties had not raised the challenge to the tribunal's jurisdiction. The EC's submission held that the agreement at issue was illegal, in so far as it contravened EU law on state aid. ${ }^{62}$ The tribunal essentially dismissed these arguments in the same way they were dismissed in Electrabel. ${ }^{63}$ Nonetheless, the tribunal ultimately found in favour of the state, dismissing all of the investor's claims.

It has been argued by some commentators that in this case (and Electrabel ${ }^{64}$ ) the EC has attempted to act as 'more than a friend' 65 of the tribunal. Indeed, it has been suggested that the EC's submissions have strayed beyond NDP participation, and into the territory of third party 'intervention'. This assertion is highly significant, because NDP participation is permitted under ICSID Rules. Third party intervention, on the other hand, is not expressly permitted under the ICSID Rules. Gerlich asserts that the main difference between participation and intervention is that NDPs participating via amicus submissions have no protected legal interest underlying in the dispute; their role is to simply assist the tribunal. On the other hand, those participating as interveners do have an interest in the outcome of the dispute. Applying this to the EC, Gerlich's argument that the EC is more of an intervener than a friend of the court is convincing. The EC clearly has a vested interest in the outcome of the disputes, given that,

\footnotetext{
59 Final award of 25 November 2015, available at https://www.italaw.com/sites/default/files/case-docum ents/italaw4495.pdf (accessed 4 October 2018).

${ }^{60}$ AES Summit Generation Ltd and others v. Republic of Hungary (ICSID Case No. ARB/07/22).

61 Electrabel SA v. Republic of Hungary, supra n. 57.

62 See TFEU, supra n. 51.

63 Electrabel SA v. Republic of Hungary, supra n. 57.

64 Ibid.

65 Gerlich (2017), pp. 253-269.
} 
The Commission presented itself as a guardian of the exclusive jurisdiction of the Court of Justice of the EU on adjudging disputes involving questions of EU law and supremacy of the EU's legal order over other international obligations of the Member States. Indeed, the Commission's function accorded to it by the EU treaties is to promote the general interest of the EU and oversee the application of EU law. Although the Commission referred to several other general objectives in its submissions, such as preventing the fragmentation of international law and forum shopping, they seem only ancillary in the light of the primary goal of protection of the EU legal order. ${ }^{66}$

Therefore, EC amicus submissions such as those seen in $A E S^{67}$ and Electrabel ${ }^{68}$ are highly significant, as they represent the only vehicle for the EC to involve itself in investment cases against member states at ICSID. The EC recognises this fact, and has attempted to push the boundaries of the mechanism of amicus submissions in order to serve its own interests. It is not suggested that this is a negative result or a disadvantage of amicus submissions; rather, it represents an important and noteworthy use of the mechanism itself. It may also provide evidence for the assertion that going forward, there should be two separate NDP procedures provided for by the ICSID Rules: participation (e.g. through amicus submissions) and intervention.

\subsubsection{Biwater Gauff v. Tanzania}

In this case, ${ }^{69}$ the investor contracted with the government of Tanzania to provide water and sewerage services for 10 years in the city of Dar es Salaam. The project was plagued by various difficulties, which ultimately culminated in the termination of the contract, as well as the deportation of company staff, and the seizure of the investor's assets. The majority of the tribunal concluded that although Tanzania did violate several provisions of the UK-Tanzania BIT, those violations were not the actual or proximate cause of the devaluation of the investor's investment. ${ }^{70}$ Indeed, the tribunal found that, by the time the expropriation took place, the investment had no economic value. The tribunal therefore dismissed the investor's claim for compensation. The only appropriate remedy was a declaration that Tanzania had violated its obligations under the BIT in certain respects, but that no compensation was due. In this way, the tribunal essentially found in favour of neither party.

In this case, the tribunal received several applications for leave to submit amicus briefs. Indeed, five non-governmental organizations [Lawyers' Environmental Action Team (LEAT); Legal and Human Rights Centre (LHRC); Tanzania Gender Networking Programme (TGNP); Center for International Environmental Law (CIEL); and the International Institute for Sustainable Development (IISD)] were

\footnotetext{
66 Ibid., p. 264.

67 AES Summit Generation Ltd and others v. Republic of Hungary, supra n. 60.

68 Electrabel SA v. Republic of Hungary, supra n. 57.

69 Biwater Gauff (Tanzania) Ltd v. United Republic of Tanzania, supra n. 28.

70 Biwater final award, http://icsidfiles.worldbank.org/icsid/ICSIDBLOBS/OnlineAwards/C67/DC158 9_En.pdf, para. 392 (accessed 3 October 2018).
} 
given permission to file Amicus curiae briefs. Their requests to have access to case documentation and to attend the oral hearing on the other hand were denied. ${ }^{71}$ It should be noted that this was actually the first time an ICSID tribunal permitted nonparties to file amicus submissions under the revised ICSID arbitration rules (rule 37). Cases before this one relied on reasoning such as that put forward in Vivendi ${ }^{72}$ for authority to accept amicus submissions.

Subsequently, the NDPs submitted a joint amicus brief to the tribunal. ${ }^{73}$ The brief argued that the investor's own acts and omissions caused its investment to fail. Additionally, it argued that investors in the water sector have a higher level of responsibility than investors in other industrial sectors, due to the fact that the success of a business in this area has a direct impact on the basic human right to clean and safe water. The amicus brief further argued that taking into consideration international human rights obligations, as well as sustainable development goals, the termination of a water-related contract by an investment host state government should not be found to be a contractual breach. The amicus submission did note that the termination of the contract should be carried out in good faith and to prevent a breach of human rights obligations. The tribunal's decision makes explicit reference to the brief: '[the] arbitral Tribunal has found the Amici's observations useful. Their submissions have informed the analysis of claims set out below, and where relevant, specific points arising from the Amici's submissions are returned to in that context. ${ }^{74}$

It is in this case that an amicus submission had the greatest effect on the outcome of any dispute. This is quite significant, given the fact that the amici were denied access to case documents and hearings. Though at the same time, it is unsurprising, due to the fact that despite the refusal of access to documents, the case was widely reported in mainstream media, and the issues at stake were relatively well known to the public. ${ }^{75}$

In the final award, the tribunal extensively analysed the arguments of the amici regarding the human right to clean and safe water (a right explicitly acknowledged by the investor itself). The tribunal recognized the core of the amici's argument; that the foreign investors failed to meet their contractual obligations, which in the context of the privatisation of the important public services actually risks reducing or destroying citizens' basic welfare. This is ironic, given that the aim of the privatisation was to enhance the welfare of citizens. Additionally, the tribunal made reference to the Millennium Development Goal to reduce the number of people without access to clean and safe water by $50 \%$. This statistic was specifically mentioned by the amici in their brief. In the final award, the tribunal also noted the amici's assertion surrounding the responsibilities of foreign investors to carry out due diligence, apply

\footnotetext{
71 See procedural order No. 5, http://icsidfiles.worldbank.org/icsid/ICSIDBLOBS/OnlineAwards/C67/ DC1584_En.pdf (accessed 3 October 2018).

72 Suez, Sociedad General de Aguas de Barcelona, S.A. and Vivendi Universal S.A. v. Argentina, supra n. 20 .

73 Joint Amicus Curiae Submission, available at, https://www.ciel.org/wp-content/uploads/2015/03/ Biwater_Amicus_26March.pdf (accessed 3 October 2018).

74 Biwater final award, supra n. 70.

75 See procedural order No. 5, supra n. 71.
} 
proper business standards, conduct effective risk assessments, act in good faith and respect the concept of pacta sunt servanda. The tribunal also restated the fact that foreign investors also bear a high level of responsibility to meet their obligations, as their investments carry significant risks for the local population of an investment host state, which is ultimately affected by the investor's investments. ${ }^{76}$

A close reading of the amicus submission and the final award demonstrates the fact that the tribunal made several lengthy and specific references to the amicus submission; this is highly significant as it shows that amicus submissions have the potential to contribute significantly to the development of the law and the policy of foreign investment (and indeed to related fields, e.g. in this case, international human rights law). However, the extent to which this has been achieved thus far is limited, as demonstrated by this study. Nonetheless, the potential for such a significant contribution is there, provided that amici have the opportunity to submit well informed briefs, and provided that the tribunal is willing to accept such briefs and actually utilise them in the decision-making process.

\subsubsection{Philip Morris v. Uruguay}

This now infamous ICSID case ${ }^{77}$ concerned the introduction of new regulatory measures by the Uruguayan government in order to reduce smoking and promote increased health. More specifically, the investor was unhappy with two specific measures introduced by the Uruguayan government. Firstly, the government required an increase in the size of graphic health warnings on cigarette packets (from $50 \%$ of the display areas of the pack, to $80 \%$ ). This measure was introduced in response to Article $11^{78}$ of the World Health Organization Framework Convention on Tobacco Control (WHO FCTC) (of which Uruguay is a member state), that obliges member states to implement 'effective measures' to ensure that tobacco products carry health warnings describing the harmful effects of tobacco products. Article 11 states that warnings should be $50 \%$ or more of the principal display areas of the pack, but no less than $30 \%$. There are guidelines for the implementation of Article 11, which are intended to help states to meet their obligations under this provision. The guidelines state, 'given the evidence that the effectiveness of health warnings and messages increases with their size, parties should consider using health warnings and messages that cover more than $50 \%$ of the principal display areas and aim to cover as much of the principal display areas as possible'. ${ }^{79}$ Secondly, the Uruguayan government banned the sale of more than one variant of a tobacco brand (known as the single-presentation requirement). This measure was intended to avoid misleading tobacco packaging. On this issue, Article 11 of the WHO FCTC obliges parties to

\footnotetext{
76 Biwater final award, supra n. 70.

77 Philip Morris Brands SARL and others v. Republic of Uruguay, supra n. 30.

78 Art. 11 FCTC, http://www.who.int/tobacco/industry/product_regulation/art_11_fctc/en/ (accessed 8 October 2018).

79 Guidelines for Implementation of Article 11, WHO FCTC, para. 12, http://www.who.int/fctc/guide lines/article_11.pdf (accessed 8 October 2018).
} 
prohibit false, misleading or deceptive terms on tobacco packaging. After Uruguay (and other states) banned such misleading terms (e.g. light/ultra-light) Philip Morris rebranded the variants (rather than withdraw them from sale). Philip Morris also took the step of informing retailers on which new variant corresponded to the prior misleading brand. In doing so, the company established an association between new variants and the banned misleading ones. ${ }^{80}$

In response to these two measures, the investor brought the case to ICSID, making a number of claims, including indirect expropriation and a breach of the obligation to provide fair and equitable treatment. To support the claims, the investor advanced various factual arguments that questioned the public health impact of the measures and various legal arguments that undermined the right to regulate under the Swiss-Uruguayan bilateral investment treaty in question. ${ }^{81}$

The tribunal received two applications to file amicus submissions (one application jointly by the WHO and the WHO Framework Convention on Tobacco Control Secretariat, and one from the Pan American Health Organization or PAHO). Both applications to file amicus submissions were allowed by the tribunal. ${ }^{82}$ The WHO/ WHO FCTC's submission described the evidence-based approach taken by the Uruguayan government towards the measures, including the examination of evidence of the risks associated with tobacco use and examining the impacts of tobacco packaging and labelling legislation. The submission went on to examine state practice in the area, and international instruments relevant to the dispute. However, 'as an independent brief, it did not take a position on how the dispute should be resolved and did not make legal arguments about interpretation of the BIT' ${ }^{83}$ The other brief (PAHO) examined tobacco control measures in the Americas. The submission expressly supported the regulatory measures undertaken by Uruguay.

The tribunal made many references to the two amicus submissions throughout the final award. ${ }^{84}$ It has been suggested that 'the appreciable impact of the submissions might be attributed partly to the identities of the amici and their functions under international law' ${ }^{85}$ Though, it was also suggested that the reason that the tribunal relied so heavily on the submissions is due to the fact that they did not focus on legal arguments; rather, they presented 'factual material that the amici were uniquely qualified to present' ${ }^{86}$

It is important to note that the two amicus briefs were submitted by intergovernmental organizations, rather than the 'traditional' amicus submissions which are most often submitted by non-governmental organizations. Seeing an increased

\footnotetext{
80 Final award, 8 July 2016, http://icsidfiles.worldbank.org/icsid/ICSIDBLOBS/OnlineAwards/C1000/ DC9012_En.pdf (accessed 8 October 2018).

81 Ibid.

82 See procedural order No. 3, http://icsidfiles.worldbank.org/icsid/ICSIDBLOBS/OnlineAwards/C1000 /DC5532_En.pdf and procedural order No. 4, http://icsidfiles.worldbank.org/icsid/ICSIDBLOBS/Onlin eAwards/C1000/DC5672_En.pdf (both accessed 8 October 2018).

83 McGrady (IISD) (2018).

${ }^{84}$ Final award, 8 July 2016, supra n. 80.

85 McGrady (IISD) (2018).

86 Ibid.
} 
number of amici, but also the diversification of amici (i.e. intergovernmental organizations, non-governmental organizations, as well as individuals) is an important development that ultimately supports the increase in the legitimacy and transparency of investment arbitration. The ICSID rules could, and indeed should, do more to promote diverse amicus submissions.

\subsubsection{Eli Lilly v. Canada}

This case ${ }^{87}$ concerned a number of pharmaceutical patents and alleged infringements of those patents by the respondent state. This case represents the first in which a tribunal issued a press release ${ }^{88}$ inviting the amicus submissions on the case from the general public. This was hailed as '[an] encouraging development [...] in light of the community interest involved in that case' ${ }^{89}$ In light of the issuance of the press release, it is unsurprising that the tribunal received a staggering nine applications to submit amicus submissions. The applications came from industry groups and private individuals. ${ }^{90}$ The tribunal accepted five out of the nine amicus applications. ${ }^{91}$ The applications for leave to file amicus submissions came from:

(i) a group of academics from the US, UK, Switzerland, South Africa and Nepal (denied-lack of standing);

(ii) the Canadian Chamber of Commerce (granted);

(iii) the Canadian Generic Pharmaceutical Association (granted);

(iv) the Samuelson-Glushko Canadian Internet Policy and Public Interest Clinic and the Centre for Intellectual Property Policy (granted);

(v) A group of academics from the University of Cambridge (denied-lack of standing);

(vi) Innovative Medicines Canada and BIOTECanada (denied as submission would not assist tribunal);

(vii) intellectual property law professors from universities in the USA (granted);

(viii) the US National Association of Manufacturers (granted);

(ix) and the Pharmaceutical Research and Manufacturers of America, Mexican Association of the Research Based Pharmaceutical Industry, and Biotechnology Innovation Organization (denied-would not assist).

In relation to the grants and refusals of the amicus applications in this particular case, it is important to note that the tribunal only ever entertained submissions from groups or individuals from NAFTA member states. Just one submission which was

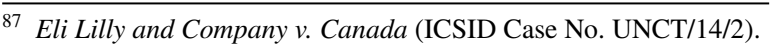

88 ICSID, News Release, Eli Lilly and Company v. Canada (ICSID Case No. UNCT/14/2), Amici Curiae (5 November 2015), https://icsid.worldbank.org/en/Pages/News.aspx?CID=155 (accessed 2 October 2018).

89 Benvenisti and Nolte (2018), p. 243.

90 See Eli Lilly and Company v. Canada, case details page, ICSID website https://icsid.worldbank.org/ en/Pages/cases/casedetail.aspx?CaseNo=UNCT/14/2 (accessed 7 October 2018).

91 Ibid.
} 
from a group of NAFTA citizens (the Pharmaceutical Research and Manufacturers of America, Mexican Association of the Research Based Pharmaceutical Industry, and Biotechnology Innovation Organization) was denied on the basis that their submission would not assist the tribunal. ${ }^{92}$ Whilst being from an affected state (or a state party to a particular free trade agreement) undoubtedly gives the petitioner an interest in the dispute, it is submitted that not being from such a state should not automatically exclude an interest (and therefore a NDP's right to participate). In some situations, NDPs from outside the state(s) in question may have an interest in the dispute, or they may be able to assist the tribunal with information that it may not receive from the parties. Therefore, excluding NDPs purely on the basis of nationality seems a little simplistic. It may have been adopted by this tribunal (and others) as a mechanism to sift through NDP amicus applications in order to save time and money, providing more evidence of a careful approach by tribunals ensuring that NDP participation should not encroach too much on arbitral procedure to the detriment of the parties. However, it is asserted that nationality in and of itself should not be a reason to exclude NDPs; rather, nationality could be one consideration a tribunal may take into account when deciding whether to allow NDP submissions. More important considerations might include: (i) the expertise of the particular potential NDP; and (ii) a legitimate interest in the dispute (which should be construed widely). Both of these considerations should take precedence over the nationality of the potential NDP.

\subsubsection{Bear Creek Mining v. Peru}

The claimant in Bear Creek ${ }^{93}$ was a Canadian company which, in 2004, found indications of significant silver deposits in the Santa Ana mine in Peru. Under Article 71 of the Peruvian Constitution, because the mine is within $50 \mathrm{~km}$ of the Peru-Bolivia border, specific authorization from the Peruvian executive was required for any foreign investor to operate the mine. To preserve its claim to the mine, the investor asked a Peruvian employee to register mining rights. After this, Bear Creek acquired the mining rights under its own name. By 2011, the company had raised finance in order to develop the site. Bear Creek asserted that it had proposed a sustainable design for the site in its impact assessment, which was subsequently approved by the government. The investor also asserted that meetings with local citizens had been well attended and largely positive in nature. However, the development of the mine suffered significant opposition, including violent protests. Residents had become concerned that mining activities were polluting nearby land and a lake. In June 2011, a new President was elected, and the Peruvian government issued a decree revoking Bear Creek's mining authorization. Accordingly, Bear Creek filed a case with ICSID. The tribunal received three applications to file an amicus submission; two were accepted and one was rejected. One accepted amicus brief was filed by Canada (as the investor's home state); this submission is not pertinent to this study.

\footnotetext{
92 Ibid.

93 Bear Creek Mining Corporation v. Republic of Peru (ICSID Case No. ARB/14/21).
} 
The tribunal also accepted a joint Amicus curiae submission containing human rights arguments, which was submitted by DHUMA (Association of Human Rights and Environment of Puno, Peru) and Mr Carlos Lopez (a Peruvian lawyer). ${ }^{94}$ The amicus application that was rejected by the tribunal was submitted by the Columbia Centre on Sustainable Investment (CCSI), which is based in New York. CCSI's application was rejected, at least in part, due to the fact that the organisation is not local to the area. ${ }^{95}$ The case was ultimately decided in favour of the investor. Notably, although CCSI's amicus application was rejected, the organisation decided to publish their application and potential brief online. ${ }^{96}$ A close reading of the potential brief and of the final award rendered by the tribunal reveals many similarities. ${ }^{97}$ It is submitted that the tribunal may have been influenced by the brief, even though its submission was formally rejected. Hence, this is the single case within the study where the amicus submissions have been classified as having an indirect effect on the outcome of the case. In addition, the other (accepted) amicus submissions had a direct effect on the outcome of the case.

\subsection{Cases Where NDP Application Was Accepted But There Was No Effect on the Outcome}

\subsubsection{Vivendi v. Argentina}

As detailed above, the first ICSID tribunal to accept an amicus submission was the panel in Vivendi ${ }^{98}$; as such, the case warrants a close analysis. The case concerned the same facts as those arising in AWG Group v. Argentina, ${ }^{99}$ and Suez and others $v$. Argentina. ${ }^{100}$ Indeed, parallel tribunals had to decide whether Argentina could justify alleged breaches of investment protection standards based on the defence of necessity. The claimants were foreign investors who had invested heavily in Argentina's water and sewerage sectors. Between 2001 and 2003, Argentina adopted emergency measures that adversely affected the claimants' businesses. After unsuccessful attempts by the claimants to renegotiate the Concessions and to withdraw from them, the Argentine government terminated the Concessions in 2006. Accordingly, the claimants brought an action, alleging indirect expropriation, a breach of the fair

\footnotetext{
94 Bear Creek Mining Corporation, case details page, ICSID website, see specifically procedural orders 5 and 6, available at https://icsid.worldbank.org/en/Pages/cases/casedetail.aspx?CaseNo=ARB/14/21 (accessed 2 October 2018).

95 Ibid. See specifically procedural order No. 6, https://www.italaw.com/sites/default/files/case-docum ents/italaw7448.pdf (accessed 2 October 2018).

96 CCSI amicus brief, http://ccsi.columbia.edu/files/2016/08/Bear-Creek-v-Peru-ARB-14-21-WrittenSubmission-CCSI.pdf (accessed 2 October 2018).

97 Ibid.

98 Suez, Sociedad General de Aguas de Barcelona, S.A. and Vivendi Universal S.A. v. Argentina, supra n. 20.

99 AWG Group v. Argentina (UNCITRAL), available at https://www.italaw.com/cases/106 (accessed 24 October 2018).

100 Suez and others v. Argentina (ICSID Case No. ARB/03/17).
} 
and equitable treatment (FET) standard and a denial of full protection and security. Argentina refuted the claims and raised various defences (including necessity) to justify any potential breach of investment protection. ${ }^{101}$ Both tribunals decided that Argentina had not expropriated the claimant's property; nor had the government breached the obligation to provide foreign investors with full protection and security. However, the tribunal did conclude that Argentina had breached its obligation to provide FET to the investors and awarded substantial damages to the claimants. The tribunal also rejected Argentina's argument of necessity. ${ }^{102}$

In January 2005, five non-governmental organizations ${ }^{103}$ filed a single request to participate in the arbitration as a NDP. ${ }^{104}$ The five organisations argued that the dispute involved issues of public interest and the fundamental rights of residents living in the area. The organisations requested that they: be allowed access to the hearings; be allowed to present legal arguments as amicus curiae; and be allowed timely, sufficient, and unrestricted access to all of the documents pertaining to the dispute. ${ }^{105}$

In February 2005, copies of the requests were sent to the claimants and the respondent who were invited to submit observations on the documents. The tribunal received observations from both parties. The claimants asked the tribunal to reject the requests in their entirety. Unsurprisingly, the respondent asked that the requests be granted. In the end, the tribunal decided to allow the organisations to have access to hearings, but no right to participate. The tribunal also decided to allow the organisations to apply for leave to submit amicus briefs and defer the request for access to documents to an appropriate time later in the case. ${ }^{106}$

Accordingly, the five organisations submitted an application to submit an amicus brief. The tribunal accepted the application, stating that the five organisations should file a single joint amicus brief electronically. Subsequently, the organisations submitted their amicus brief. ${ }^{107}$ It should be noted that the tribunal was clearly very keen to balance the interests of NDPs with those of the parties themselves. ${ }^{108}$ Indeed, commentators have noted that, 'although the decision-makers in this case emphasized that the amicus curiae could bring new perspectives to the proceeding,

\footnotetext{
101 Suez, Sociedad General de Aguas de Barcelona, S.A. and Vivendi Universal S.A. v. Argentina, supra n. 20 .

102 Ibid.

103 Asociación Civil por la Igualdad y la Justicia (ACIJ), Centro de Estudios Legales y Sociales (CELS), Center for International Environmental Law (CIEL), Consumidores Libres Cooperativa Ltda. de Provisión de Servicios de Acción Comunitaria, and Unión de Usuarios y Consumidores.

104 Details are given about the organisations' request in the tribunal's response to the request. See 'Order in response to a petition by five non-governmental organisations for permission to make an amicus curiae submission', https://www.italaw.com/sites/default/files/case-documents/ita0823.pdf (accessed 1 October 2018).

105 Ibid.

106 Ibid.

107 Amicus Curiae Submission of the five organisations is available online, http://www.ciel.org/Publi cations/SUEZ_Amicus_English_4Apr07.pdf (accessed 1 October 2018).

108 Suez, Sociedad General de Aguas de Barcelona, S.A. and Vivendi Universal S.A. v. Argentina, supra n. 20, Order in Response to a Petition for Transparency and Participation as Amicus Curiae.
} 
they also highlighted the importance of not unduly burdening the disputing parties with broad third-party intervention'. ${ }^{109}$

In terms of the content of the submission, the brief essentially argued that the Argentinean government's actions were justified under international human rights law, 'human rights law provides a rationale for these measures, and that this rationale is relevant to the interpretation and application of Bilateral Investment Treaties (BITs)' ${ }^{110}$ The organisations went on to state that, 'more particularly, human rights law recognizes the right to water and its close linkages with several other human rights, including the right to life, health, housing, and an adequate standard of living. ${ }^{111}$ Accordingly, the five organisations argued that international human rights law places an obligation on the Argentinean government to ensure access to water for the entire population (that obligation includes both physical and economic access to water). The five organisations therefore believed that the measures adopted by the Argentinean government (which included particularly the freezing of the tariff levels during the economic crisis) were designed to ensure that Argentinean citizens should have access to water. The organisations therefore advanced the argument that the measures adopted by the government had to be adopted in order that the government should satisfy its obligations under international human rights law. ${ }^{112}$ This essentially echoes the respondent government's arguments based on necessity.

As noted above, the tribunal found in favour of the claimant investors in terms of the allegation against the Argentinean government that it had breached its obligation to provide fair and equitable treatment, but the tribunal dismissed the other allegations (expropriation and full protection and security). In its final award, the tribunal did not make any explicit or implicit reference to the information put forward by the five organisations in their joint amicus brief. This in itself is very telling. This is the first ICSID case in which a tribunal takes the highly momentous decision to enable NDPs to submit an amicus brief, yet the tribunal seemingly takes no notice of the brief itself in its final award. Why the tribunal chose to take this course of action is highly significant. The benefits of allowing amicus submissions, i.e. greater transparency, enhanced legitimacy, public interest in cases et cetera are well documented ${ }^{113}$; however, it is submitted that the ICSID tribunal (at the very least) took inspiration from the panel in the Methanex case ${ }^{114}$ in accepting an amicus brief, and (at the most) perhaps felt quite pressurised to do so. This could explain its willingness to accept NDP submissions. As to why the tribunal would go to considerable effort to allow such submissions, only to seemingly ignore them in its final decision, the issue here could be one of practicality. In reality, a close reading of the amicus submission ${ }^{115}$

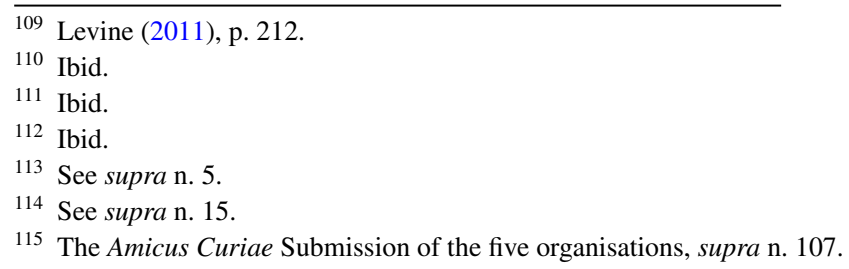


itself and other available case documents ${ }^{116}$ demonstrates that the information and arguments presented by the NDPs very closely reflect the submissions and arguments of the respondent. Therefore, no particularly novel or useful information was submitted to the tribunal by the NDPs, which is why the tribunal did not feel the need to explicitly or implicitly utilise material contained in the submission. Despite the fact that the NDP submission itself did not prove particularly useful for the tribunal on this occasion, the very fact that the tribunal allowed the submission demonstrates a significant commitment on the part of the arbitrators to enhancing NDP participation in investment arbitration, which in turn does enhance both the transparency and legitimacy of the mechanism. Additionally, the case catalysed the amendment to the ICSID Rules, which ultimately formalised the acceptance of and the procedure for the submission of amici curiae. ${ }^{117}$ Thus, the impact of this case on NDP participation should not be underestimated.

\subsubsection{Merrill and Ring Forestry v. Canada}

This case ${ }^{118}$ concerned export controls imposed by the provincial government of Canada, which permitted the export of logs only on the condition that the logs themselves are deemed surplus to local requirements. Additionally, local landowners were subject to exemptions from the export controls, whereas federally regulated landowners (such as the investors) were not. The investors alleged that the Canadian government had breached NAFTA obligations concerning: national treatment; most favoured nation; expropriation; minimum standards of treatment; and performance requirements. The tribunal found in favour of Canada, dismissing all of the investor's claims. ${ }^{119}$

In this case, an application to submit an amicus brief by joint submission by two organisations was accepted. ${ }^{120}$ The submission, ${ }^{121}$ it is asserted, had no direct or indirect effect on the outcome of the case. The tribunal did not mention it in its final award, nor is there any indication that the tribunal was inspired by the brief upon a close reading of the brief itself and the final award. ${ }^{122}$ This demonstrates the wide discretion that the tribunal possesses; not only discretion as to whether or not to even accept the participation of a NDP through an amicus submission, but further,

\footnotetext{
116 ICSID website, Vivendi case materials, https://icsid.worldbank.org/en/Pages/cases/casedetail .aspx?CaseNo=ARB/03/19 (accessed 1 October 2018).

117 See supra n. 22.

118 Merrill and Ring Forestry LP v. Canada (ICSID Case No. UNCT/07/1).

119 Ibid.

120 The organisations were: the United Steel Workers, Communications, Energy and Paperworkers Union of Canada, and the British Colombia Federation of Labour. See Letter from tribunal accepting amicus submission application, http://icsidfiles.worldbank.org/icsid/ICSIDBLOBS/OnlineAwards/C5406 /DC7876_En.pdf (accessed 4 October 2018).

121 Amicus Curiae Submission by the United Steel Workers, Communications, Energy and Paperworkers Union of Canada, and the British Colombia Federation of Labour, http://icsidfiles.worldbank.org/icsid/ ICSIDBLOBS/OnlineAwards/C5406/DC7879_En.pdf (accessed 4 October 2018).

122 See amicus submission, ibid., and the final award of the tribunal, available at http://icsidfiles.world bank.org/icsid/ICSIDBLOBS/OnlineAwards/C5406/DC7890_En.pdf (accessed 4 October 2018).
} 
discretion regarding consideration or non-consideration of the submission. It seems to be a waste of time and money to allow submissions from NDPs, only to seemingly ignore them. The sole justification for this might be if the amicus brief brings nothing new to the table and simply reiterates facts and opinions put forward by the parties themselves or other case documents and submissions. However, even if this is the case, one could reasonably expect that the tribunal at least makes some reference to the amicus submission in its final decision, even if it is to simply say that the tribunal did not find the submission pertinent or useful.

\subsubsection{Foresti v. South Africa}

In this case ${ }^{123}$ a group of investors claimed that South Africa effectively withdrew their mining rights without providing adequate compensation. The investors alleged that their investment was indirectly expropriated by the enactment of human rights legislation, which was intended to improve the situation of a number of South African citizens who had been marginalized prior to this. Two applications for leave to submit an amicus brief were submitted by a group of four NGOs, and the International Commission of Jurists. ${ }^{124}$ The amicus applications were granted by the tribunal; however, the case was discontinued before a final award. ${ }^{125}$ Therefore, it is impossible to know whether the amicus submissions may have ultimately affected the outcome of the case, although for the reasons explained below it is asserted that it is likely that the NDP submission would certainly have had an effect, given the tribunal's obvious commitment to NDP participation.

Despite its discontinuance, the case is extremely significant, as the tribunal introduced a number of innovations to the process of NDP participation. ${ }^{126}$ Even though a final award was never issued, in a procedural order, ${ }^{127}$ and its default award on costs, ${ }^{128}$ the tribunal made some key statements on NDP participation. This case was actually the first ICSID dispute in which the tribunal granted the amici access to some case documents, namely parties' filings (despite objections to doing so from one party). ${ }^{129}$ Furthermore, the tribunal stated that it would invite the parties and the NDP participants to provide feedback concerning the procedure proscribed for NDP participation in the dispute. ${ }^{130}$

\footnotetext{
123 Piero Foresti, Laura de Carli and others v. The Republic of South Africa (ICSID Case No. $\mathrm{ARB}(\mathrm{AF}) / 07 / 1)$.

124 Procedural order, http://icsidfiles.worldbank.org/icsid/ICSIDBLOBS/OnlineAwards/C90/DC2392_ En.pdf (accessed 8 October 2018).

125 See Award, 4 August 2010, para. 25, available at http://icsidfiles.worldbank.org/icsid/ICSIDBLOBS/ OnlineAwards/C90/DC1651_En.pdf (accessed 4 October 2018).

126 IISD, 'An ICSID tribunal introduces innovative steps in non-disputing party procedure', https://www. iisd.org/itn/2009/10/10/an-icsid-tribunal-introduces-innovative-steps-into-non-disputing-party-procedure/ (accessed 4 October 2018).

127 Procedural order, 25 September 2009, http://icsidfiles.worldbank.org/icsid/ICSIDBLOBS/Onlin eAwards/C90/DC2391_En.pdf (accessed 4 October 2018).

128 Award, 4 August 2010, supra n. 125.

129 Ibid.

130 See Procedural order, 25 September 2009, supra n. 127 and Award, 4 August 2010, supra n. 125.
} 
Additionally, the tribunal committed to discussing the comments of the parties and the NDP participants in its final award. ${ }^{131}$

\subsubsection{Pac Rim v. El Salvador}

Pac $\operatorname{Rim}^{132}$ acquired various mining exploration licences in El Salvador, with a number of licences pertaining to some of the state's poorest regions. Having verified that one area contained significant high-grade gold reserves, Pac Rim wished to convert an exploration licence into an exploitation concession. The application for the exploitation concession failed to include certain documents required under Salvadorian law, e.g. an environmental permit and the consent of the landowners of parts of the property. Consequently, the Salvadorian authorities proposed an amendment to the law to expressly limit the required documentation to the area affected by the mine's infrastructure. If approved, the amendment would reduce the number of documents to be produced by the investor. The authorities supported the approval of the amendment, but in the meantime, the authorities also requested the submission of the missing documents required by current law. The missing documents were never submitted, and Parliament rejected the legislation amendment. Soon after, the President said that he was against granting new mining exploitation permits, and one year later, he specifically stated that Pac Rim would not be granted a concession. Pac Rim brought the case to ICSID, and eventually, the tribunal dismissed on their merits all claims by Pac Rim against El Salvador. The tribunal ordered Pac Rim to pay US\$8 million towards El Salvador's legal costs. ${ }^{133}$

The tribunal granted one NDP application in this case after ICSID issued a press release inviting such submissions. ${ }^{134}$ Accordingly, an amicus brief was submitted by the Center for International Environmental Law (CIEL) on behalf of several nonprofit organizations. ${ }^{135}$ The brief argued that El Salvador's measures were supported by its international obligations on human rights and the environment. However, the tribunal did not consider it necessary to address CIEL's arguments, because the disputing parties did not consent to disclose the factual evidence to CIEL, and because the tribunal's decisions 'do not require the Tribunal specifically to consider the legal case advanced by CIEL: and, in the circumstances, it would be inappropriate for the Tribunal to do so'. ${ }^{136}$

This case is particularly significant, because the tribunal actively sought amici curiae applications by the publication of a press release, accepted an application to

\footnotetext{
131 Ibid. For more detail on this case and the significance for non-disputing party participation see Leibold (2016), p. 215.

132 Pac Rim Cayman LLC v. Republic of El Salvador (ICSID Case No. ARB/09/12).

133 Final award of 14 October 2016, https://www.italaw.com/sites/default/files/case-documents/itala w7640_0.pdf (accessed 4 October 2018).

134 ICSID news release, 2 February 2011, available at https:/www.italaw.com/sites/default/files/casedocuments/ita0608.pdf (accessed 4 October 2018).

135 See Amicus Curiae Submission of CIEL, https://www.ciel.org/wp-content/uploads/2014/06/PacRi m_AmicusEng_25Jul2014.pdf (accessed 4 October 2018).

136 Final award of 14 October 2016, supra n. 133, para. 3.30.
} 
submit a brief from the NDP (CIEL), but then the tribunal refused to take it into account because CIEL did not have access to documents (at the request of the parties). Therefore, the acceptance of the brief in itself seems absolutely pointless. Indeed, the procedural order accepting the application of the NDP is actually very telling in this regard. The tribunal was at pains to state several times that amicus participation should not disrupt the procedure. ${ }^{137}$ It could be argued that the tribunal did the minimum to satisfy the requirements regarding NDP participation in the amended ICSID Rules, and absolutely no more than that. This is perhaps an indication of arbitrators' attitudes favouring speed and cost concerns over procedural legitimacy and transparency of process. Not all tribunals act in this manner; however, the fact that tribunals have so much discretion when it comes to NDP participation is the problematic point.

\subsection{Cases Where NDP Application Was Denied}

\subsubsection{Caratube v. Kazakhstan}

This case ${ }^{138}$ concerned the revocation of an American investor's licence to run an oilfield in Kazakhstan, and an allegation that the investor had been harassed by the authorities in Kazakhstan. The tribunal ultimately decided the case in favour of the state. Notably, in this case, leave to submit an amicus brief was not granted by the tribunal. ${ }^{139}$ No detail was given by the tribunal in the final award as to the identity of the NDP petitioner, or as to why the tribunal did not permit the submission of the brief. ${ }^{140}$ As the application to submit a brief was not accepted, there could not have been an effect on the outcome of the case.

This case demonstrates that the decision as to whether to accept an amicus submission is completely at the discretion of the tribunal, which is not required to give reasons for its decision in any procedural order or final award (though it is submitted that it could be construed as good practice on the part of the tribunal to do so). The lack of transparency in this case regarding the NDP is regrettable, and provides evidence that the reform of the rules regarding NDP participation is necessary to protect the integrity and utility of the mechanism.

\footnotetext{
137 Procedural order on amicus curiae, http://icsidfiles.worldbank.org/icsid/ICSIDBLOBS/OnlineAwar ds/C661/DC2011_En.pdf (accessed 4 October 2018).

138 Caratube International Oil Company LLP v. The Republic of Kazakhstan (ICSID Case No. $\mathrm{ARB} / 08 / 12)$.

139 See final award, 5 June 2012, https://www.italaw.com/sites/default/files/case-documents/italaw1100 .pdf, p. 35 (accessed 4 October 2018).

140 Ibid.
} 


\subsubsection{The Apotex Cases}

Similarly to the Caratube case above, ${ }^{141}$ in this dispute ${ }^{142}$ an application for leave to submit an amicus brief by a NDP was declined. However, unlike in Caratube, ${ }^{143}$ the tribunal did explain the reasons for its rejection of the amicus application. In this case, the NDP that applied to submit an amicus brief was the Study Center for Sustainable Finance. The Center is 'the research and development arm of the Business Neatness Magnanimity (BNM) SRL'. ${ }^{144}$ In rejecting the request, the tribunal stated that the application did not meet the criteria for NDP participation. The tribunal rejected the Center's application to submit a brief, because: such a submission would not be of assistance to the tribunal; the Center had no interest in the case; and finally, the Center had not identified 'the particular public interest it would be seeking to address through its proposed submission'. ${ }^{145}$ The case was ultimately decided in favour of the state. Here, the tribunal took a sensible approach, declining the participation of a private management consulting firm that describes itself as a 'per profit non-governmental organisation' ${ }^{146}$ that had no discernible interest in the case, and was unable to demonstrate any wider public interest. However, it should be noted that the tribunal rejected the application in a highly transparent manner by issuing a procedural order, which was ultimately published. Tribunals need to be mindful of accepting NDP submissions simply for the sake of it, where there is no discernible benefit or interest, exercising discretion carefully and in a transparent manner. ICSID Rules could be amended to reflect this, by expressly requiring tribunals to give detailed reasons for their refusal of NDP submissions, rather than simply assuming the tribunal will do so as a matter of good practice.

The claimant made a second attempt ${ }^{147}$ to sue the US government. Like the previous case, this one was decided in favour of the state, with the tribunal dismissing the investor's claims. In the second case, the tribunal issued an invitation for amicus curiae submissions, ${ }^{148}$ and subsequently two amicus applications (one from a Canadian lawyer and the other from a company named BNM which had applied to submit a brief in the previous Apotex case ${ }^{149}$ ) were rejected by the tribunal. ${ }^{150}$ The tribunal rejected both requests on a combination of the following grounds:

\footnotetext{
141 Caratube International Oil Company LLP v. The Republic of Kazakhstan, supra n. 138.

142 Apotex Inc v. The Government of the United States (ICSID Case No. UNCT/10/2).

143 Caratube International Oil Company LLP v. The Republic of Kazakhstan, supra n. 138.

144 See procedural order No. 2, https://www.italaw.com/sites/default/files/case-documents/ita0033.pdf (accessed 4 October 2018).

145 Ibid., p. 10.

146 Ibid., p. 3.

147 Apotex Holdings Inc and Apotex Inc v. The Government of the USA (ICSID Case No. $\mathrm{ARB}(\mathrm{AF}) / 12 / 1)$.

148 ICSID news release, 31 January 2013, available at https://www.italaw.com/sites/default/files/casedocuments/italaw1253.pdf (accessed 4 October 2018).

149 Apotex Inc v. The Government of the United States, supra n. 142.

150 See procedural order rejecting BNM's application, https:/www.italaw.com/sites/default/files/casedocuments/italaw1320.pdf (accessed 7 October 2018) and procedural order rejecting Mr. Appleton's (the Canadian lawyer) application, https://www.italaw.com/sites/default/files/case-documents/italaw1320.pdf (accessed 7 October 2018).
} 
(i) they would not be of any assistance to the tribunal;

(ii) they did not address matters within the scope of the dispute;

(iii) they did not demonstrate a significant interest in the dispute;

(iv) and they did not explain why the matters at stake were in the public interest.

The rejection of the amicus applications in this dispute is unsurprising (especially BNM's application) given that the tribunal in the previous Apotex case reached the same decision. Mr. Appleton (the Canadian lawyer) was found by the tribunal to have some connection with the claimant, therefore the rejection of his application is also unsurprising. Once again though, clear reasons for declining the amicus applications were given by the tribunal, therefore the process appears to be transparent. Additionally, the reasons given do appear to be robust and just. This is perhaps an example of a case in which amicus applications (specifically rejections) were well handled by the tribunal. Though, this probably says more about the handling and professionalism of the individual arbitrators than about the process proscribed in ICSID Rules, which gives a lot of discretion to arbitrators. This provides evidence for the assertion that the Rules themselves should be reformed, in order to ensure consistency across the board, rather than leaving it to the discretion of individual arbitrators.

\subsection{Cases Which Were Discontinued: S\&T Oil Equipment and ENGIE}

The $S \& T$ case $^{151}$ was discontinued before a decision was made by the tribunal as to whether or not to allow an amicus submission. The ENGIE case was registered with ICSID in April 2016. ${ }^{152}$ The case concerned a French/Dutch investor suing Hungary under the Energy Charter Treaty. In March 2017 a NDP filed an application to make an amicus submission. The tribunal made a decision on the application by the NDP in July 2017 in a procedural order, and the case was eventually discontinued in February 2018. ${ }^{153}$ No documents have subsequently been released concerning this case, therefore it is impossible to analyse the effect that the amicus submission may have had on the case. Indeed, it is unknown whether the application to submit a brief was even accepted by the tribunal. Although not the main concern of this study, this lack of the publication of case information highlights the prioritisation of confidentiality over transparency within ICSID as an institution, and is reflected in the current version of its arbitration rules. This prioritisation of confidentiality within investment treaty arbitration, and within the Centre itself specifically has been fiercely criticised by commentators. ${ }^{154}$

\footnotetext{
151 S\&T Oil Equipment and Machinery v. Romania (ICSID Case No. ARB/07/13).

152 ENGIE SA, GDF International SAS and ENGIE International Holdings BV v. Hungary (ICSID Case No. ARB/16/14); see procedural details section on ICSID website, https://icsid.worldbank.org/en/Pages/ cases/casedetail.aspx?CaseNo=ARB/16/14 (accessed 2 October 2018).

153 Ibid.

154 See generally Paulsson and Rawding (1995) and for ICSID specifically see Egonu (2007), p. 479.
} 


\section{Findings and Recommendations}

The analysis of the participation of NDPs (by means of amici curiae submissions) in ICSID cases herein demonstrates that amicus briefs are grossly underutilised. This study has found that in the 309 concluded cases since the landmark case of Vivendi ${ }^{155}$ where the first ICSID tribunal accepted an amicus submission, there have been only 16 applications from NDPs wishing to participate in ICSID cases. Of the 16 applications, just 11 applications to participate were granted. Further, of the 11 applications that were granted, only in seven cases did the amicus submission affect the outcome of the case (in six cases, the outcome was directly affected, and in one case, the outcome was both directly and indirectly affected). There is some evidence to suggest that over time the acceptance of amicus submissions and their effect on the outcome of ICSID cases have increased. This is to be expected, as it often takes time for new procedures to be adopted and effect change. It could therefore also be argued that increased numbers and effects of amicus submissions are also actively leading to the increased relevance of human rights in investment disputes; several of the cases analysed demonstrate that amicus submissions frequently make reference to human rights issues, which are then potentially picked up by the tribunal itself. Significantly, an examination of arbitral panels revealed no evidence that the outcome of cases was unduly affected by the attitudes of individual arbitrators in these cases.

However, the study has revealed much more than just disappointing statistics regarding the underuse of amici curiae at ICSID. A thorough critical analysis of the 16 cases in which applications were made by NDPs to participate via amici curiae has revealed that ICSID tribunals have a lot of discretion to decline ${ }^{156}$ submissions (and they are not reluctant to do so). Out of 16 applications to participate, five were not explicitly permitted (in three the application was denied, in one the case was discontinued before a decision on amicus was made, and in another, a decision seems to have been made but that decision remains unpublished). Additionally, this work has shown that even when amicus applications are granted, tribunals appear to ignore the content of amicus submissions. ${ }^{157}$ One of the main reasons that tribunals may be seen to be ignoring information in amicus briefs is that they often repeat points ${ }^{158}$ raised in other case documents, e.g. party submissions. Frequently, NDPs submit briefs to support respondent states; indeed, in all of the cases analysed the NDPs submitted information supporting respondent states, rather than claimant investors. A further point highlighted by this study is that amicus submissions may be pointless if the petitioner(s) do(es) not have access to case documents, e.g. Pac Rim. ${ }^{159}$ In

\footnotetext{
155 Suez, Sociedad General de Aguas de Barcelona S.A. and Vivendi Universal S.A v. Argentine Republic, supra n. 20.

156 See for example Caratube International Oil Company LLP v. The Republic of Kazakhstan, supra $\mathrm{n}$. 138 and Apotex Inc v. The Government of the United States, supra n. 142.

157 See for example the Merril case, supra n. 118.

158 This was the case in Vivendi, supra n. 20 and in Micula, supra n. 47.

159 Pac Rim Cayman LLC v. Republic of El Salvador, supra n. 132.
} 
most cases, where applications were made from NDPs, the applicants also requested access to documents and hearings. ${ }^{160}$ Usually, such requests for access are denied by tribunals (often at the request of the parties); this was the case in Pac Rim ${ }^{161}$ itself. This exacerbates the issue of the repetition of information and arguments in amicus submissions; because without access to all relevant case documents, the petitioner does not know what issues have already been raised by the parties themselves.

The study has also raised important questions about the limits of the amicus participation mechanism, and whether a second intervention procedure should be introduced under the ICSID framework. As demonstrated by the cases above in which the EU Commission submitted amicus briefs, intervention may be more appropriate for NDPs who have an interest in the outcome of the dispute.

As mentioned above, an important observation from the statistics uncovered in this study is that the submission of amicus briefs often coincides with a favourable outcome for the state. This is probably unsurprising, given that amicus applications are usually submitted by NGOs and citizens who tend to campaign for the public interest, rather than that of the private investor. Out of 11 cases where an application to submit an amicus brief was accepted, in six cases the respondent state emerged as the 'winner'. Out of the six cases where the state 'won', in four cases there was deemed to be a direct or indirect effect of the amicus brief. This correlation is to be expected; given that the majority of briefs support state positions (as opposed to supporting the investor's claims), we would reasonably expect to see more state 'wins' in cases where briefs have been submitted. This also demonstrates that amicus briefs can potentially have an important impact regarding legitimacy concerns about states (public entities) being sued before private tribunals. Greater participation through amicus submissions (which, as demonstrated here, often support state positions) can increase the legitimacy of investment arbitration by promoting the public interest, which in turn promotes the rule of law. In order to realize the full potential and effect that amicus submissions could have in the settlement of investment disputes under the auspices of ICSID, this article makes two key recommendations designed to increase the use and utility of amicus submissions.

\subsection{Possible Amendments to ICSID Rules}

Firstly, an ICSID Rule amendment is necessary regarding the participation of NDPs in order to fully maximize the potential benefits of the mechanism. This suggestion is timely, as ICSID is currently consulting on a proposed set of rule amendments. ${ }^{162}$ Many of the current ISCID rule amendment proposals concern the participation of NDPs (and transparency more generally). A detailed analysis of the proposed rule amendments as they relate to NDPs and transparency is beyond the scope of this work. However, a brief consideration of the tabled proposals is merited, as a

\footnotetext{
160 See for example the Biwater case, supra n. 28.

161 Pac Rim Cayman LLC v. Republic of El Salvador, supra n. 132.

162 'About ICSID Amendments', available at https://icsid.worldbank.org/en/amendments/Pages/About/ about.aspx (accessed 1 October 2018).
} 
judgement can be made on the appropriateness of the proposals to address concerns raised by this study regarding NDPs.

In terms of enhancing transparency, more generally, the ICSID amendments propose that awards will be published with the consent of the parties; however, a new provision sets out the presumption of such consent after 60 days if a party does not object in writing. If a party does object, ICSID will publish only legal excerpts. Additionally, decisions and orders will be published within 60 days, with redactions agreed by the parties. If the parties cannot agree on redaction, the tribunal will decide any disputes. Further, parties will be able to publish other documents with agreed redaction on the ICSID website procedural details section for each case. An important proposal is that the tribunal shall allow open hearings (subject to logistical arrangements to preserve confidential information). Additionally, ICSID will publish recordings and transcripts of hearings. Open hearings and publication will be subject to neither party's objections.

In terms of the amendment proposals relating to NDPs, ICSID proposes to continue the process for the participation of NDPs, but adding further criteria for consideration as to whether to allow a NDP written submission. Firstly, identification of the activities of the NDP; secondly, the disclosure of any affiliation with a disputing party; and thirdly, disclosure as to whether the NDP has received any assistance with its filing or submission. The proposed rule would also give the tribunal the discretion to order NDPs to contribute to the increased cost attributable to their participation (extra time, comments on participation et cetera). Finally, the tribunal may order that the NDP should receive documents relevant to the case (subject to objection by either party). Additionally, it is proposed that a non-disputing treaty party should be permitted to file a written submission on the application or interpretation of the treaty in question. A party wishing to file a written submission on other matters within the scope of the dispute would have to apply to be a NDP in the traditional sense, using already existing procedures. ${ }^{163}$

It is important to note that the proposed ICSID Rules on transparency would apply only where there is no specific treaty (e.g. an investment treaty or the Mauritius Convention) applicable and if there is no case-specific agreement on the issue.

These proposed rule amendments would certainly go a long way to remedying many of the problems associated with NDP participation via amicus submissions within ICSID that have been highlighted in this study. For example, publishing more awards and documents relating to the dispute and having open hearings would allow third parties to have more access to the dispute. Additionally, should the third party wish to submit an amicus brief, it will almost certainly be in possession of a greater number of and more accurate facts than is presently the case. However, concerns may be raised about exceptions to publication and open hearings; if parties would be very easily able to successfully object to greater transparency, the amendments would be rendered useless. As regards the proposals relating to NDPs, the disclosure proposals could put additional burdens on NDPs wishing to submit amicus briefs

\footnotetext{
163 'Proposals for Amendment of the ICSID Rules', working paper, available at https://icsid.worldbank. org/en/Documents/Amendments_Vol_Three.pdf (accessed 1 October 2018).
} 
(e.g. if the rules are interpreted in such a way that negative perceptions or suspicion attach to having received help with a submission). Most troubling, though, is the proposal to allocate costs to NDPs in recognition of the extra time and costs associated with their participation in the dispute. This financial burden may be enough to dissuade certain parties from submission, i.e. NGOs and other organisations that often have overstretched budgets. This deterrence would be a great shame, depriving the tribunal of significant information, which may not otherwise come to light from the submissions of the parties themselves. Additionally, morally, those NDPs who may have an interest in the case or have been affected (negatively) by the investment or the issues relating to the dispute may not be able to participate in the dispute.

Finally, it should be noted that these proposed amendments are currently only under consultation by ICSID at the moment. As such, there is no concrete guarantee these proposals will actually come to fruition in their entirety or even at all. Even more worryingly, if they are introduced, they could enhance some aspects of NDP participation and transparency but potentially have a very detrimental effect on others. For example, there is no mention of compulsory press releases to alert NDPs to the fact that disputes are happening and that they can get involved. Additionally, tribunals will still possess great discretion as to whether to accept amicus applications in the first place, and there will be no requirement for the tribunal to give detailed reasons for its decision should it choose to decline an application. It is also important to note that the proposed amendments do not include the provision of a secondary intervention procedure (in addition to the NDP participation mechanism through the submission of amicus briefs), which could be beneficial to NDPs that may have a substantial interest in the outcome of a dispute, such as the European Commission. Finally, there is no proposed provision to ensure that ICSID tribunals take into account amicus submissions in the decision-making process. There is also no mention of clarifying the requirements that must be met by potential amicus applicants in order to submit a brief. Clarification of nationality matters, the expertise of the amicus applicant and how public interest in a case might be demonstrated is also not included. Therefore, the first recommendation of this article undoubtedly has to be to amend the ICSID Rules, but that the precise amendments themselves are considered very carefully from the perspective of NDP and transparency. The current amendment proposals put forward by ICSID are insufficient to protect NDP participation in ICSID procedures and to ensure maximum benefits can be realised from NDP participation.

\subsection{Other Steps to Encourage Greater NDP Participation}

Firstly, guidelines could be issued to arbitrators on the procedural aspects of third party participation and the utilisation of amicus submissions in the decision-making process. This will, for example, enable them to understand criteria for the acceptance of amicus applications, realise the importance of giving detailed justification for the refusal of amicus applications, and contemplate how amicus submissions can be used to assist tribunals. A second suggestion would be mandatory institutional training for arbitrators on issues related to amici curiae submissions. ICSID 
could create a training course to help arbitrators better understand the rationale for amicus submissions and how to utilise them to assist the tribunal most effectively. The course could be based around the content of the proposed arbitrator guidelines. A third suggestion would be for ICSID to encourage amicus submissions by publicising the opportunities, e.g. advertising in relevant publications (e.g. practitioner publications and publications with a more general readership such as newspapers and online media) and to relevant networks (e.g. NGO networks) and making press releases inviting amicus submissions mandatory in every case (as suggested above). Fourthly, ICSID could also consider issuing guidelines to potential amicus applicants to help them understand all aspects of the NDP process at ICSID. This would help to ensure that the prospective amicus applicants meet the necessary criteria to apply to submit a brief, and help them to understand what information they may wish to include in their brief to aid the tribunal.

\section{Conclusion}

The main conclusion of the study is that amicus briefs do have the potential to positively impact investment arbitration under the auspices of ICSID. ${ }^{164}$ However, at present, amicus submissions are not utilised within the ICSID framework to their full potential to provide maximum benefits. This is probably due to ICSID's prioritisation of the balancing of the interests of the parties themselves and external (NDP) interests, as evidenced in Vivendi. ${ }^{165}$ Whilst encouraging a higher number of amicus briefs and more diverse amici should be an aim of ICSID, it is conceded that this recommendation may not be easily achieved in light of the Centre's prioritisation of balancing NDP participation with the interests of the disputing parties. If ICSID does accept that it should strive to enhance its NDP participation mechanism, this will need to be achieved by means of a more comprehensive rules amendment than the one currently being undertaken. Additionally, further practical steps beyond a Rules amendment will need to be taken to enhance the NDP participation mechanism.

Going forward then, amicus submissions could be a very useful tool for ICSID investment tribunals, if utilised to their maximum potential. Indeed, amici curiae could make a key contribution to the development of investment law and policy and better integrate investment and human rights law, by promoting balanced interpretations of investor protection provisions and supporting state positions. Additionally, as demonstrated, amicus submissions can enhance transparency and legitimacy of investor-state dispute settlement (ISDS), which in turn enhances the rule of law. This would go a long way to silencing many of the critics of the current system of ISDS, and particularly of ICSID as an institution.

164 This positive potential influence was highlighted in the Biwater case for example, supra n. 28.

165 See Vivendi, supra n. 20. 
Open Access This article is distributed under the terms of the Creative Commons Attribution 4.0 International License (http://creativecommons.org/licenses/by/4.0/), which permits unrestricted use, distribution, and reproduction in any medium, provided you give appropriate credit to the original author(s) and the source, provide a link to the Creative Commons license, and indicate if changes were made.

\section{References}

Antonietti A (2006) The 2006 amendments to the ICSID Rules and Regulations and the Additional Facility Rules. ICSID Rev Foreign Invest Law J 21:427-448

Bartholomeusz L (2005) The amicus curiae before international courts and tribunals. Non-State Actors Int Law 5:209-286

Benvenisti E, Nolte G (eds) (2018) Community interests across international law. Oxford University Press, Oxford

Blackaby $\mathrm{N}$ et al (2010) Amicus curiae: a panacea for legitimacy in investment arbitration? In: Waibel $\mathrm{M}$ et al (eds) The backlash against investment arbitration: perceptions and reality. Kluwer International, Alphen aan den Rijn, pp 253-274

Cawley J (2004) Friend of the court: how WTO justifies the acceptance of the amicus curiae brief from non-governmental organisations. Penn State Int Law Rev 23:47-78

Chandra Mohan S (2010) The amicus curiae: friends no more? Singap J Legal Stud 52:352-374

Choudhury B (2008) Recapturing public power: is investment arbitration's engagement of the public interest contributing to the democratic deficit? Vanderbilt J Transnatl Law 41:775-832

Crema L (2012) Testing amici curiae in international law: rules and practice. Ital Yearb Int Law 22:91-132

de Brabandere E (2011) NGOs and the 'public interest': the legality and rationale of amicus curiae intervention in international economic and investment disputes. Chic J Int Law 12:85-113

de Mestral A (ed) (2017) Second thoughts: investor-state arbitration between developed democracies. Centre for International Governance Innovation, Waterloo

Dimsey M (2008) The resolution of international investment disputes: international commerce and arbitration. Eleven International Publishing, Utrecht

Egonu M (2007) Investor-state arbitration under ICSID: a case for presumption against confidentiality? J Int Arbitr 24:479-490

Footer M (2013) International investment law and trade: the relationship that never went away. In: Baetens $\mathrm{F}$ (ed) Investment law within international law: integrationist perspectives. Cambridge University Press, Cambridge, pp 259-297

Franck S (2005) The legitimacy crisis in investment treaty arbitration: privatising public international law through inconsistent decisions. Fordham Law Rev 73:1521-1526

Gerlich G (2017) More than a friend? The European Commission's amicus curiae participation in investor-state arbitration. In: Adinolfi $\mathrm{G}$ et al (eds) International economic law: contemporary issues. Springer, Cham, pp 253-270

Hindelang S, Krajewski M (eds) (2016) Shifting paradigms in international investment law: more balanced, less isolated, increasingly diversified. Oxford University Press, Oxford

Howse R (2007) Membership and its privileges: the WTO, civil society, and the amicus brief controversy. In: Howse R (ed) The WTO system: law, politics and legitimacy. Cameron May, London, pp 57-75

Kulick A (ed) (2016) Reassertion of control over the investment treaty regime. Cambridge University Press, Cambridge

Langford M, Behn D, Lie R (2017) The revolving door in international investment arbitration. J Int Econ Law 20:301-332

Leader S (2006) Human rights, risks, and new strategies for global investment. J Int Econ Law 9:657-705

Leibold A (2016) The friction between investor protection and human rights: lessons from Foresti v. South Africa. Houst J Int Law 38:215-267

Levine $\mathrm{E}$ (2011) Amicus curiae in international investment arbitration: the implications of an increase in third party participation. Berkeley J Int Law 29:200-224

Mavroidis P (2002) Amicus curiae briefs before the WTO: much ado about nothing. In: von Bogdandy A et al (eds) European integration and international co-ordination: studies in transnational economic law in honour of Claus-Dieter Ehlermann. Kluwer Law International, The Hague, pp 317-329 
McGrady B (IISD) (2018) The influential amici in Philip Morris v. Uruguay: a new role for intergovernmental organizations in investment treaty arbitration?. https://www.iisd.org/library/influential-amici -philip-morris-v-uruguay-new-role-intergovernmental-organizations. Accessed 8 October 2018

Mistelis L (2005) Confidentiality and third-party participation: UPS v. Canada and Methanex Corp. v. USA. In: Weiler T (ed) International investment law and arbitration. Cameron May, London, pp 169-199

Paulsson J, Rawding N (1995) The trouble with confidentiality. Arbitr Int 11:303-320

Reinisch A (2016) The rule of law in international investment arbitration. In: Pazartis P et al (eds) Reconceptualising the rule of law in global governance, resources, investment and trade. Hart, Oxford, pp 291-307

Shelton D (1994) The participation of nongovernmental organizations in international judicial proceedings. Am J Int Law 88:611-642

Stern B (2011) The future of international investment law: a balance between the protection of investors and the states' capacity to regulate. In: Alvarez J, Sauvant K (eds) The evolving international investment regime: expectations, realities, options. Oxford University Press, New York, pp 174-192

Trakman L (2014) Confidentiality in international commercial arbitration. Arbitr Int 18:1-18

van Duzer J (2007) Enhancing the procedural legitimacy of investor-state arbitration through transparency and amicus curiae participation. McGill Law J 52:681-724

van Harten G (2005) Private authority and transnational governance: the contours of the international system of investor protection. Rev Int Political Econ 12:600-623

van Harten G, Loughlin M (2006) Investment treaty arbitration as a species of global administrative law. Eur J Int Law 17:121-150

Waibel M, Kaushal A, Chung K, Balchin C (eds) (2010) The backlash against investment arbitration: perceptions and reality. Kluwer Law International, Alphen aan den Rijn

Wiik A (2018) Amicus curiae before international courts and tribunals. Nomos, Baden-Baden

Zachariasiewicz M (2012) Amicus curiae in international investment arbitration: can it enhance the transparency of investment dispute resolution. J Int Arbitr 29:205-224

Publisher's Note Springer Nature remains neutral with regard to jurisdictional claims in published maps and institutional affiliations. 